\title{
Significant Heterogeneity in terms of Diagnosis and Treatment of Renal Cell Carcinoma at a Private and Public Hospital in Brazil
}

\author{
Marcos F. Dall'Oglio, Rafael Coelho, Roberto Lopes, Alberto A. Antunes, Alexandre Crippa, \\ Cesar Camara, Katia R. M. Leite, Miguel Srougi
}

University of São Paulo, Medical School, Urology Division, São Paulo, Brazil and Instituto do Câncer do Estado de São Paulo Octávio Frias de Oliveira

\begin{abstract}
Purpose: A great number of small renal lesions have now been detected. Nowadays, partial nephrectomy has more frequently been adopted for surgical treatment of earlier stage disease. Previous studies have associated patient, institutional, and health care system factors with surgery type. The aim of this study was to compare the diagnosis and treatment of renal cell carcinoma (RCC) according to hospital type, public versus private, in our country.

Materials and Methods: We retrospectively evaluated 183 patients with RCC who underwent radical nephrectomy or nephron-sparing surgery between 2003 and 2007 in two hospitals, one private and one public. Patient demographic, clinical, surgery, and pathologic characteristics were analyzed.

Results: The radical nephrectomy rate was higher at the public hospital than at the private hospital $(75 \% \mathrm{vs.} 57 \%, \mathrm{p}=$ 0.008). Overall, patients at the public hospital presented larger tumors than did the patients who were cared for privately. Furthermore, small renal masses were significantly more prevalent in private care $(57.8 \%$ vs. $28.3 \%)$. Patients at the public hospital showed a higher incidence of capsular invasion $(\mathrm{p}=0.008)$, perirenal fat invasion $(\mathrm{p}<0.01)$, lymph node involvement ( $\mathrm{p}<0.001)$, and a lower incidence of initial tumors. pT1 tumors were reported in $41 \%$ of patients at the public hospital and in $72 \%$ at the private hospital $(\mathrm{p}<0.001)$.

Conclusion: Patients with RCC cared for at our public referral hospital showed a more advanced stage than RCC treated at the private institution.
\end{abstract}

Key words: nephrectomy; carcinoma; renal cell; neoplasm staging; prognosis

Int Braz, J Urol. 2011; 37: 584-590

\section{INTRODUCTION}

Approximately 200000 new cases of renal cell cancer (RCC) are diagnosed all over the world every year, constituting the third most common genitourinary cancer, following bladder and prostate cancers (1). Indeed, RCC is one of the most lethal urological tumors; it is believed that $40 \%$ of RCC-diagnosed patients will die as a result of such disease, approximately 100000 deaths per year all over the world (2). Moreover, the annual incidence of RCC has increased $2.5 \%$, which is attributed at least in part to the widespread use of non-specific abdominal imaging $(3,4)$. The current RCC series in literature shows that $60-70 \%$ of the patients are asymptomatic at the diagnosis (5). This change in the incidental presentation of renal mass doubled the prevalence of the localized disease from 1975 to 1995 (6,7). Paradoxically, despite diagnosis and early treatment, there has been an increase in the overall and diseasespecific mortality rates in the last twenty years, according to SEER (Surveillance, Epidemiology, and End Results Program) database (8). In spite of 
that, there are groups of patients with small, nonaggressive tumors which can be dealt with with conservative treatment or with only surveillance.

In Brazil there have been no data collected addressing the epidemiological profile of RCC. Therefore, the current incidence of incidental and symptomatic tumors and their respective staging and treatment is not known. The aim of this study was to evaluate the symptoms at diagnosis (incidental and symptomatic), the size of the tumors, the type of surgery performed (radical and conservative), the TNM stage and the anatomopathological characteristics of the sporadic RCC who are treated in two tertiary hospitals, one public and another private, in our country.

\section{MATERIALS AND METHODS}

We performed a retrospective study in which we reviewed prospectively collected data from 183 patients who underwent surgical treatment for RCC between July 2003 and December 2007 in two tertiary hospitals in Brazil. Ninety-three patients were treated at a public hospital (Hospital das Clínicas da Faculdade de Medicina de Sao Paulo), and ninety patients at a private hospital (Sociedade Beneficente de Senhoras Hospital Sírio-Libanês-Sao Paulo).

The data evaluated included the clinical presentation at the diagnosis (incidental or symptomatic), the type of surgery performed (conservative or radical) and anatomo-pathological characteristics (histological type, presence of sarcomatous differen- tiation, Furhman's nuclear grading system, presence of microvascular invasion, tumor size and TNM stage) 14 . These characteristics were comparatively analyzed between the public and private hospital patients.

Postoperative follow-up included abdominal computed tomography and/or ultrasonography and hematological exams every four months during the two initial years, and every six months from the third to the fifth year. When the last consultation had taken place more than three months earlier, there was a telephone confirmation of the patient's current health condition.

For the statistical analysis the student's ttest and chi-square test were used. Results with pvalues inferior to $5 \%(\mathrm{p}<0.05)$ were considered significant. Both institutions' review boards approved the study prior to accruing the patients, and informed consent was signed by all participants.

\section{RESULTS}

The median age was equivalent in both groups ( 56 vs. 60 years; $p=0.204$ ). There was predominance of male patients at the private hospital compared to the public hospital (90\% vs. $61.3 \%$; $\mathrm{p}<$ 0.001) (Table-1).

The diagnosis of the symptomatic tumors at the public hospital is $47.3 \%$ vs. $33.3 \%$ (Table-2). At the private hospital, there was a higher rate of patients with hematuria, whereas the public hospital showed a higher rate of patients presenting the classical triad

Table 1 - Demographic data.

\begin{tabular}{|c|c|c|c|c|}
\hline & & \multicolumn{2}{|c|}{ Hospital } & \multirow[b]{2}{*}{ p-value } \\
\hline & & $\begin{array}{l}\text { Private } \\
(n=90)\end{array}$ & $\begin{array}{c}\text { Public } \\
(n=93)\end{array}$ & \\
\hline \multirow[t]{3}{*}{ Sex } & & & & $<0.001$ \\
\hline & Female & $9(10.0 \%)$ & $36(38.7 \%)$ & \\
\hline & Male & $81(90.0 \%)$ & $57(61.3 \%)$ & \\
\hline \multirow[t]{3}{*}{ Age } & & & & 0.204 \\
\hline & Median (Q1-Q3) & $56(49-67)$ & $60(53-67)$ & \\
\hline & Min - Max & $23-87$ & $20-91$ & \\
\hline
\end{tabular}


Table 2 - Clinical presentation of RCC and type of surgery performed.

\begin{tabular}{cccc}
\hline & \multicolumn{3}{c}{ Hospital } \\
\cline { 2 - 3 } & $\begin{array}{c}\text { Private } \\
(\mathbf{n}=\mathbf{9 0})\end{array}$ & $\begin{array}{c}\text { Public } \\
(\mathbf{n}=\mathbf{9 3})\end{array}$ & p-value \\
\hline Clinical Presentation & & & 0.059 \\
Incidental & $60(66.7 \%)$ & $47(52.8 \%)$ & 0.008 \\
Symptomatic & $30(33.3 \%)$ & $42(47.3 \%)$ & \\
Surgery Performed & & $23(24.7 \%)$ & \\
Partial & $39(43.3 \%)$ & $70(75.3 \%)$ \\
\hline
\end{tabular}

(hematuria/pain/palpable mass). It is also worth noting that more patients presented metastatic disease at diagnosis at the public hospital when compared to the private hospital (Table-3).

The proportion of conservative surgery practically doubles at the private hospital $(\mathrm{p}=0.008)$ (Table-2). The median tumor size was significantly different in both hospitals (Table-4): the median size was smaller than $4 \mathrm{~cm}$ at the private hospital and larger than $6 \mathrm{~cm}$ at the public hospital $(\mathrm{p}<0.001)$. Another remarkable finding is that $58 \%$ of the tumors at the private hospital are smaller than $4 \mathrm{~cm}$ against only $28 \%$ at the public hospital $(\mathrm{p}<0.001)$.

The pathological characteristics of the RCC in both hospitals are represented in Table-4. The public hospital patients presented locally advanced tumors, with higher percentage of capsular invasion $(p=0.008)$, perirenal fat invasion $(p=0.01)$, and presence of lymph node metastasis $(p<0.001)$. The percentage of pT1 tumors was higher at the private hospital than at the public hospital (72\% vs. $41 \%$; $p<$ 0.001) (Figure 1).

Table 3 - Symptoms at diagnosis.

\section{Hospital}

\begin{tabular}{lcc}
\hline Symptoms & Private & Public \\
\hline Hematuria & $8(8.6 \%)$ & $47(52.2 \%)$ \\
Pain & $10(10.7 \%)$ & $28(31.1 \%)$ \\
Weight Loss & - & $6(6.6 \%)$ \\
Metastasis & $4(4.4 \%)$ & $7(7.5 \%)$ \\
Palpable Mass & $5(5.5 \%)$ & $8(8.6 \%)$ \\
Hematuria / Pain / Palpable Mass & $9(10 \%)$ & $13(13.9 \%)$ \\
Others & $7(7.7 \%)$ & - \\
\hline
\end{tabular}


Table 4 - Pathological characteristics.

\begin{tabular}{|c|c|c|c|}
\hline & \multicolumn{2}{|c|}{ Hospital } & \multirow[b]{2}{*}{ p-value } \\
\hline & $\begin{array}{l}\text { Private } \\
(n=90)\end{array}$ & $\begin{array}{c}\text { Public } \\
(\mathrm{n}=93)\end{array}$ & \\
\hline Character & & & 0.997 \\
\hline Single & $83(92.2 \%)$ & $71(92.2 \%)$ & \\
\hline Multiple & $7(7.8 \%)$ & $6(7.8 \%)$ & \\
\hline Histological Type & & & $<0.001$ \\
\hline Clear cells & $62(68.9 \%)$ & $69(86.3 \%)$ & \\
\hline Bellini Duct & - & $1(1.3 \%)$ & \\
\hline Papillary & $20(22.2 \%)$ & - & \\
\hline Chromophobe & $6(6.7 \%)$ & $8(10.0 \%)$ & \\
\hline Sarcomatous Degeneration & $7(7.8 \%)$ & $4(4.4 \%)$ & \\
\hline Degree Fuhrman & & & 0.627 \\
\hline Low (I and II) & $58(65.2 \%)$ & $48(61.5 \%)$ & \\
\hline High (III and IV) & $31(34.8 \%)$ & $30(38.5 \%)$ & \\
\hline Fat Invasion & & & 0.011 \\
\hline No & $79(87.8 \%)$ & $54(72.0 \%)$ & \\
\hline Yes & $11(12.2 \%)$ & $21(28.0 \%)$ & \\
\hline Microvascular invasion & & & 0.469 \\
\hline No & $64(71.1 \%)$ & $42(65.6 \%)$ & \\
\hline Yes & $26(28.9 \%)$ & $22(34.4 \%)$ & \\
\hline Capsular Invasion & & & 0.008 \\
\hline No & $71(78.9 \%)$ & $54(60.7 \%)$ & \\
\hline Yes & $19(21.1 \%)$ & $35(39.3 \%)$ & \\
\hline Positive Lymph node & & & $<0.001$ \\
\hline No & $89(98.9 \%)$ & $19(63.3 \%)$ & \\
\hline Yes & $1(1.1 \%)$ & $11(36.7 \%)$ & \\
\hline Renal Sinus invasion & & & 0.331 \\
\hline No & $24(63.2 \%)$ & $18(75.0 \%)$ & \\
\hline Yes & $14(36.8 \%)$ & $6(25.0 \%)$ & \\
\hline Staging & & & $<0.001$ \\
\hline $\mathrm{T} 1$ & $64(71.9 \%)$ & $38(40.9 \%)$ & \\
\hline $\mathrm{T} 1 \mathrm{a}$ & $52(58,3 \%)$ & $26(28,1 \%)$ & \\
\hline $\mathrm{T} 1 \mathrm{~b}$ & $12(13,6 \%)$ & $12(12,8 \%)$ & \\
\hline $\mathrm{T} 2$ & $3(3.4 \%)$ & $21(22.6 \%)$ & \\
\hline $\mathrm{T} 3$ & $19(21.3 \%)$ & $28(30.1 \%$ & \\
\hline $\mathrm{T} 4$ & $3(3.4 \%)$ & $6(6.4 \%)$ & \\
\hline Tumor size $(\mathrm{cm})$ & & & $<0.001$ \\
\hline Median (Q1-Q3) & $3.9(2.6-5.5)$ & $6.3(4.0-10.8)$ & \\
\hline Min - Max & $1.2-14.5$ & $0.8-24.0$ & \\
\hline & & & $<0.001$ \\
\hline$\leq 4 \mathrm{~cm}$ & $52(57.8 \%)$ & $26(28.3 \%)$ & \\
\hline$>4 \mathrm{~cm}$ & $38(42.2 \%)$ & $66(71.7 \%)$ & \\
\hline
\end{tabular}




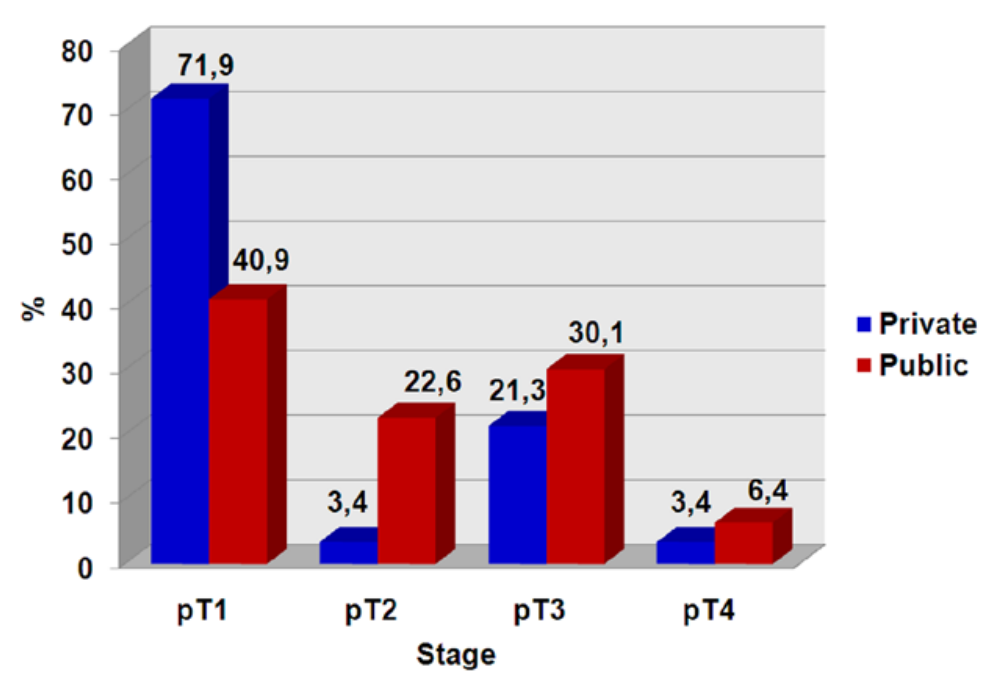

Figure 1 - RCC pathological staging according to the source hospital.

\section{DISCUSSION}

There were marked differences in the clinical presentation, type of surgery performed and histological findings of the RCC treated at public and private hospitals in Brazil. The median size of RCC detected at the private hospital was $2.4 \mathrm{~cm}$, smaller than those detected at the public hospital. Nephron-sparing surgery was performed in half of the patients at the public hospital when compared to the private one. Furthermore, whereas approximately $60 \%$ of the patients operated on at the private hospital had tumors smaller than $4 \mathrm{~cm}$, more than $70 \%$ of the public hospital patients presented tumor larger than $4 \mathrm{~cm}$. pT1 RCC tumors occurred in $72 \%$ of the private hospital patients and in only $40 \%$ of the public hospital patients. Therefore, the fact that the public hospital is an academic teaching environment and the private is essentially a private practice probably did not play such an important role in determining the surgical approach in our study as did the tumor stage.

Differences in RCC histology between the groups reported in the present study may be associated with the disparate median tumor sizes. Patients with small renal masses (SRM) were probably less frequently referred to the public hospital, since it is a tertiary referral institution.
Radical nephrectomy was a rather common option in the public hospital, comprising $75 \%$ of renal surgeries, whereas at the private hospital, radical nephrectomy was performed in 57\% of the cases. Long-term functional results for the patients who have undergone radical and conservative nephrectomy are very different . Lau et al. (9) have reported that the progression towards renal insufficiency (creatinine $>2 \mathrm{mg} / \mathrm{dL}$ ) ten years after the renal surgery occurred in $22.4 \%$ of the patients who were submitted to radical nephrectomy versus $11.6 \%$ after partial nephrectomy.

$\mathrm{RCC}$ is a classically aggressive tumor; in clinical series from developed countries, onethird of the patients present metastasis at the diagnosis (10). Indeed, more than $40 \%$ of the RCC patients die due to that disease (11). The risk of death caused by RCC may be higher in developing countries like Brazil, especially in public hospitals. In our study, symptomatic and metastatic tumors comprised $47 \%$ and $15 \%$, respectively, of the tumors treated at public hospitals and 33\% and $4 \%$ of the tumors treated at private hospitals. In the United States, $25-30 \%$ of the patients initially present with metastatic RCC (12).

Today, more than $60 \%$ of RCC cases are incidentally detected in developed countries. $(8,12-16)$. Nevertheless, in the present study, in- 
cidental diagnosis occurred in $67 \%$ of Brazilian private hospital patients and $53 \%$ of public hospital patients. Since the Brazilian public health system is based on universal coverage for approximately 203 million people, of which $68 \%$ have no private health insurance, medical visits and tests are often delayed due to long waiting lists (17).

The 2002 TNM presented a new proposal for the RCC stage, especially in T1 tumors (smaller than $7 \mathrm{~cm}$, restricted to the kidney) (14). RCC stage $\mathrm{T} 1$ includes tumors with different outcomes. For instance, the likelihood of death within ten years for a patient with a $5-\mathrm{cm}$, low-degree RCC is less than 3\%; however, a high-degree $5-7 \mathrm{~cm}$ RCC has a $40 \%$ likelihood of death in ten years (18). In Brazilian private and public hospitals approximately $72 \%$ and $41 \%$ of the patients presented stage pT1 tumors, respectively. Considering that life expectancy for T1 tumors is much higher, we can expect a higher RCC mortality at the Brazilian public institutions than at private hospital, a rather peculiar characteristic for our country. At the public hospital the classical triad (hematuria/ pain/palpable mass), identified in $28 \%$ of the public hospital patients and $8 \%$ of the private hospital patients, respectively - can still be found.

An important limitation is that both are distinct pathology services and the surgeon's experience at the private hospital is higher. The data from public hospitals on diagnosis of metastatic disease are probably underestimated, and it is possible that data are actually higher.

Currently, renal masses are detected incidentally, with smaller sizes constituting the ideal cases for conservative surgery $(19,20)$. However, recent series from developed countries showed that conservative kidney surgery has been underutilized; only $9.6 \%$ of the surgeries carried out due to RCC are conservative (21). In this context, our study showed that nephron-sparing surgery was carried out in $43 \%$ and $24 \%$ of private and public hospital individuals, respectively. Although not broadly representative, these two particular hospitals may indirectly reflect the patterns of care in the private and public health systems in Brazil. Nonetheless, an external validation of these findings is needed to confirm this discrepancy.

\section{CONCLUSIONS}

Patients with RCC operated on at a tertiary public hospital in Brazil showed a more technically advanced histopathological evaluation than those treated at a private institution, reflecting the different standards of treatment that patients may undergo according to their socioeconomic level.

\section{CONFLICT OF INTEREST}

None declared.

\section{REFERENCES}

1. Jemal A, Siegel R, Ward E, Hao Y, Xu J, Thun MJ: Cancer statistics, 2009. CA Cancer J Clin. 2009; 59: 225-49.

2. Wotkowicz C, Libertino JA: Renal cell cancer: radical nephrectomy. BJU Int. 2007; 99: 1231-8.

3. Chow WH, Devesa SS, Warren JL, Fraumeni JF Jr: Rising incidence of renal cell cancer in the United States. JAMA. 1999; 281: 1628-31.

4. Lam JS, Belldegrun AS, Pantuck AJ: Long-term outcomes of the surgical management of renal cell carcinoma. World J Urol. 2006; 24: 255-66.

5. Parsons JK, Schoenberg MS, Carter HB: Incidental renal tumors: casting doubt on the efficacy of early intervention. Urology. 2001;57: 1013-5.

6. Hock LM, Lynch J, Balaji KC: Increasing incidence of all stages of kidney cancer in the last 2 decades in the United States: an analysis of surveillance, epidemiology and end results program data. J Urol. 2002; 167: 57-60.

7. Jayson M, Sanders H: Increased incidence of serendipitously discovered renal cell carcinoma. Urology. 1998; 51: 203-5.

8. Hollingsworth JM, Miller DC, Daignault S, Hollenbeck BK: Rising incidence of small renal masses: a need to reassess treatment effect. J Natl Cancer Inst. 2006; 98: 1331-4.

9. Lau WK, Blute ML, Weaver AL, Torres VE, Zincke $\mathrm{H}$ : Matched comparison of radical nephrectomy vs nephron-sparing surgery in patients with unilateral renal cell carcinoma and a normal contralateral kidney. Mayo Clin Proc. 2000; 75: 1236-42. 
10. Lam JS, Shvarts O, Leppert JT, Figlin RA, Belldegrun AS: Renal cell carcinoma 2005: new frontiers in staging, prognostication and targeted molecular therapy. J Urol. 2005; 173: 1853-62.

11. Srinivasan R, Armstrong AJ, Dahut W, George DJ: Anti-angiogenic therapy in renal cell cancer. BJU Int. 2007; 99: 1296-300.

12. Crispen PL, Uzzo RG: The natural history of untreated renal masses. BJU Int. 2007; 99: 1203-7.

13. Janzen NK, Kim HL, Figlin RA, Belldegrun AS: Surveillance after radical or partial nephrectomy for localized renal cell carcinoma and management of recurrent disease. Urol Clin North Am. 2003; 30: 843-52.

14. Sobin LH, Wittekind Ch: TNM classification of malignant tumors. 6th ed. New York, Wiley-Liss. 2002; pp. 193-5.

15. Knight DA, Stadler WM: Prognostic factors in localized renal cell cancer. BJU Int. 2007; 99: 12126.

16. Coll DM, Smith RC: Update on radiological imaging of renal cell carcinoma. BJU Int. 2007; 99: 1217-22.

17. Brasil. Instituto Brasileiro de Geografia e Estatística. Um panorama da saúde no Brasil: acesso e utilização dos serviços, condições de saúde e fatores de risco e proteção à saúde 2008. Brasília, DF: Ministério da Saúde; Ministério do Planejamento, Orçamento e Gestão; 2008. Available from: http:// www.ibge.gov.br/home/estatistica/populacao/ panorama_saude_brasil_2003_2008/default.shtm. [cited 2010 Set 12]

18. Lau WK, Cheville JC, Blute ML, Weaver AL, Zincke H: Prognostic features of pathologic stage T1 renal cell carcinoma after radical nephrectomy. Urology. 2002; 59: 532-7.
19. Frank I, Blute ML, Cheville JC, Lohse CM, Weaver AL, Zincke H: Solid renal tumors: an analysis of pathological features related to tumor size. J Urol. 2003; 170: 2217-20.

20. Patard JJ, Dorey FJ, Cindolo L, Ficarra V, De La Taille A, Tostain J, et al.: Symptoms as well as tumor size provide prognostic information on patients with localized renal tumors. J Urol. 2004; 172: 2167-71.

21. Hollenbeck BK, Taub DA, Miller DC, Dunn RL, Wei JT: National utilization trends of partial nephrectomy for renal cell carcinoma: a case of underutilization? Urology. 2006; 67: 254-9.

Submitted for publication:

May 25, 2010

Accepted after revision:

April 11, 2011 